\title{
WINALPecobase - ecological database of mountain forests in the Bavarian Alps
}

\author{
Birgit Reger, Ralf Schüpferling, Josefine Beck, Elke Dietz, Daniel Morovitz, Roman \\ Schaller, Gerhard Wilhelm \& Jörg Ewald
}

\begin{abstract}
WINALPecobase (GIVD ID EU-DE-003) is an ecological database of mountain forest plots in the Bavarian Alps (Germany). Created in 2009, the database features the following characteristics: (1) 1,505 georeferenced forest relevés with concomitant soil profile descriptions, (2) placement across the whole study area (ca. $4,600 \mathrm{~km}^{2}$ ) according to a design that combines systematic and stratified sampling, (3) consistent standards for vegetation and soil inventory, and (4) extensive quality control of the database. The database is available for collaborative research.
\end{abstract}

Keywords: ecoinformatics; forest type; soil data; vegetation data.

Abbreviations: GIS = Geographic Information System; GPS = Global Positioning System; NFI 2 = Second National Forest Inventory; WINALP $=$ Waldinformationssystem Nordalpen (Forest Information System for the Northern Alps).

Received: 26 August 2010 - Accepted: 2 May 2011 - Co-ordinating Editor: Jürgen Dengler.

\section{Introduction}

Mountain forests provide many important ecological landscape functions and services (e.g. protection of human settlements and infrastructure against natural hazards). Maintenance, enhancement and restoration of mountain forests are therefore main goals of sustainable forest management. To effectively protect and restore vulnerable forest ecosystems, to improve management practices, and to adapt forest stands to predicted changes in climate, forest managers require detailed information on vegetation and site conditions.

Within our INTERREG IV A-project „Forest Information System for the Northern Alps“ (WINALP; http://www. winalp.info, Ewald 2009, Ewald \& Reger 2012), which aims at developing GISbased, high-resolution and spatially explicit information on the natural potential of the mountain forests in the Northern Alps, we conducted a detailed plot inventory of vegetation types, plant species and soil properties and developed the digital database WINALPecobase.

\section{Sampling and sampling design}

The inventory of mountain forest vegetation and soil was conducted in 2009 (seven plots in 2010) for a total of 1,505 forest plots in the Bavarian Alps, a mountain range in Southern Germany (Fig. 1). The mountain range comprises an area of ca. $4,600 \mathrm{~km}^{2}$, of which $53 \%$ are currently covered by forest. The study area was subdivided into ten inventory regions. Each inventory region was investigated by an inventory team including a vegetation ecologist and a soil scientist. The sampling was conducted in a combined systematic and stratified design in order to ensure an area-wide, representative, multivariately balanced data recording. The systematic sampling design was based on the regular $4 \mathrm{~km} \times 4 \mathrm{~km}$ squared grid (in the Allgäu Alps in the western part and the Mangfall range in the central part of the Bavarian Alps on the denser $2 \mathrm{~km} \times$ $2 \mathrm{~km}$ squared grid) of the second National Forest Inventory (NFI 2, in German Bundeswaldinventur; Federal Ministry of Food, Agriculture and Consumer Protection 2005) in Germany. Each square consists of four coordinate points with a distance of $150 \mathrm{~m}$, of which at least one is located in a forest stand. The first inventory plot location was randomly selected out of one to four possible coordinate points of the NFI 2 square. The selected plot was the starting point of a contour line of approx. $2 \mathrm{~km}$ length (Fig. 1). The contour lines and the plots were georeferenced by a GPS-system and integrated in a GIS. Along the contour line forest site types were continuously mapped according to a field manual that combines criteria of ground vegetation, stand structure, relief and soil (Ewald \& Binner 2007), resulting in line sections (strata) with unique forest types. The stratified contour line served as the basis for the placement of four additional inventory plots within sections of differing forest types. Plot locations were chosen in mature stands with tree layer composition and structure corresponding as closely as possible to the natural vegetation of the forest types. Surveying teams were instructed to achieve even sampling of all forest types within an inventory region, thus securing maximal spread of sample plots along local and regional environmental gradients.

For each inventory plot, general data like geographic location, topographic variables and forest site type were recorded. Around each inventory plot, a relevé area of $14 \mathrm{~m} \times 14 \mathrm{~m}$ was defined. Within each relevé, all vascular plants, epigeic 
bryophytes and lichen species and their total cover were recorded separately according to vegetation layers. Species growing on rocks, roots and dead wood were excluded from recording. Species cover was assessed according to six-point cover scale, simplified after BraunBlanquet (1964). Within the vegetation plots, soil profiles were normally inspect- ed in auger samples. The survey focused on soil description in horizons (soil type) combined with a description of the parent materials in terms of components and genesis (substrate). Additionally, the humus development and groundwater level was recorded. The description of the soil profiles followed the standards of German soil survey (Ad-hoc-
Arbeitsgruppe Boden 2005). Soil colour of the horizons, stratigraphy and petrography of the fine and coarse components, geogenesis of the substrate as well as the substrate layers were described according to the standards of the Bavarian Environment Agency (LfU).

\begin{tabular}{|c|c|}
\hline GIVD Database ID: EU-DE-003 & Last update: $2012-04-28$ \\
\hline \multicolumn{2}{|l|}{ WINALPecobase } \\
\hline \multicolumn{2}{|c|}{ Scope: WINALPecobase is an ecological database of mountain forest plots in the Bavarian Alps (Germany). } \\
\hline Status: finished & Period: $2009-2010$ \\
\hline \multicolumn{2}{|c|}{ Database manager(s): Jörg Ewald (joerg.ewald@hswt.de) } \\
\hline \multicolumn{2}{|l|}{ Owner: Jörg Ewald } \\
\hline \multicolumn{2}{|l|}{ Web address: http://www.winalp.info } \\
\hline Availability: free upon request & Online upload: no \\
\hline Database format(s): MS Access & Export format(s): MS Access, Excel, CSV file \\
\hline \multicolumn{2}{|l|}{ Publication: $[\mathrm{NA}]$} \\
\hline Plot type(s): normal plots & Plot-size range: $196-196 \mathrm{~m}^{2}$ \\
\hline Non-overlapping plots: 1,505 & Estimate of existing plots: 7,000 \\
\hline Total plot observations: 1,505 & Number of sources: [NA] \\
\hline \multicolumn{2}{|l|}{ Countries: AT: 0.3\%; DE: $99.7 \%$} \\
\hline \multicolumn{2}{|l|}{ Forest: $[\mathrm{NA}]$ - Non-forest: [NA] } \\
\hline \multicolumn{2}{|c|}{ Guilds: all vascular plants: $100 \%$; bryophytes (terricolous or aquatic): $89 \%$; lichens (terricolous or aquatic): $4 \%$} \\
\hline \multicolumn{2}{|c|}{$\begin{array}{l}\text { Environmental data: altitude: } 100 \% \text {; slope aspect: } 98 \% \text {; slope inclination: } 100 \% \text {; microrelief: } 82 \% \text {; soil depth: } 100 \% \text {; other soil attributes: } 100 \% \text {; } \\
\text { land use categories: } 99 \%\end{array}$} \\
\hline \multicolumn{2}{|c|}{ Performance measure(s): cover: $100 \%$} \\
\hline \multicolumn{2}{|c|}{ Geographic localisation: GPS coordinates (precision $25 \mathrm{~m}$ or less): $100 \%$} \\
\hline \multicolumn{2}{|c|}{ Sampling periods: $2000-2009: 99.5 \% ; 2010-2019: 0.5 \%$} \\
\hline Information as of 20 & rther details and future updates available from http://www.givd.info/ID/EU-DE-003 \\
\hline
\end{tabular}

\section{Database and database struc- ture}

The recorded data of the inventory plots were integrated in the digital database WINALPecobase. The database was realised in MS Access and designed as a relational data model with seven tables including general data on the inventory plots, vegetation data and soil data (Fig. 2).

The database contains a total of 904 vascular plant (the most frequent being Picea abies, Acer pseudoplatanus, Oxalis acetosella and Fagus sylvatica), 238 bryophyte (Polytrichum formosum, Dicranum scoparium and Hylocomium splendens) and 21 lichen taxa (Cladonia pyxidata and Parmelina pastillifera). Vegetation plots contain on average 34 $(\min =2, \max =89)$ vascular plant taxa and $7(\min =0, \max =40)$ bryophyte taxa. Concerning the soil data, 1505 soil profiles were recorded. Among them, cambisols (Braunerde), cambisol-rendzinas, and rendzinas are dominating. The most frequent humus forms are F-mull (414 plots) and L-mull (349). In total, all 47 forest types were identified (Table 1), the most frequent being Fagion forest types (923 plots), subalpine coniferous forest types (119) and montane coniferous forest types (117).

Table 1: Frequency of forest types and inventory plots according to groups of forest types.

\begin{tabular}{lcc}
\hline $\begin{array}{l}\text { Group of forest } \\
\text { types }\end{array}$ & $\begin{array}{l}\text { Number } \\
\text { of forest } \\
\text { types }\end{array}$ & $\begin{array}{c}\text { Number } \\
\text { of plots }\end{array}$ \\
\hline Fagion & 9 & 923 \\
Subalpine coniferous & 7 & 119 \\
Montane coniferous & 9 & 117 \\
Tilio-Acerion & 6 & 100 \\
Luzulo-Fagion & 2 & 95 \\
Alno-Ulmion & 3 & 56 \\
Subalpine krummholz & 3 & 41 \\
Non-forest & 6 & 37 \\
Erico-Pinion & 1 & 15 \\
Salicion eleagni & 1 & 2 \\
\hline
\end{tabular}

The vegetation relevés will be transferred to existing data pools like the German national online databank VegetWeb (http://www.floraweb.de/vegetation/aufna hmen.html, Ewald et al. 2006) and BERGWALD (Ewald 1995, 2012).

\section{Quality control}

The quality of the vegetation and soil data recorded in the field was assured and checked by various quality-control methods. Recording in the field was coordinated by a pre-meeting and three midterm meetings in the field with the inventory teams. Data entering in the database was controlled by four fixed-format standard forms with compulsory data entries (e.g. number of the inventory unit), 28 predefined selection lists (e.g. taxon list adopted from the electronic reference list GermanSL (Jansen \& Dengler 2008), list of fine soil texture) and limits for numerical values (e.g. aspect from $0^{\circ}$ to $360^{\circ}$ ). Field data entries were checked for plausibility using 87 automated SQL tests, 
which were implemented with the script language Python (e.g. soil type gley must have a Go- and Gr-horizon). Additionally, a soil expert examined data coherence and compatibility on the field sheets. Laboratory analyses were not conducted.

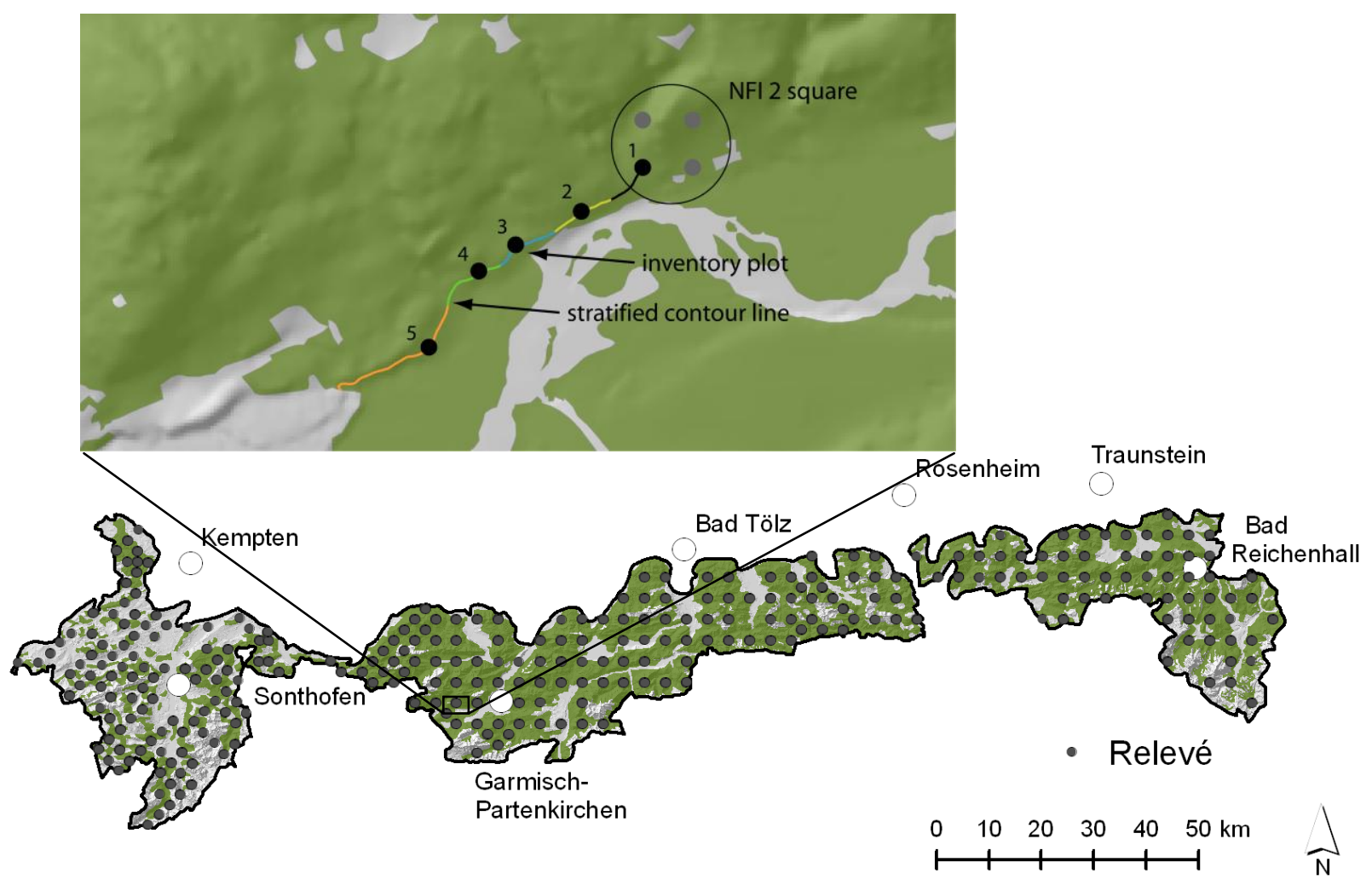

Fig. 1: Location of the NFI 2 squares arranged in a regular $4 \mathrm{~km} \times 4 \mathrm{~km}$ grid (in the Allgäu Alps in the western part and the Mangfall range in the central part of the Bavarian Alps in a $2 \mathrm{~km} \times 2 \mathrm{~km}$ grid) within the study area and an example of a stratified contour line (each colour representing a forest type) with five inventory plots. Data source: Digital elevation model from the Bavarian Surveying Administration (LVG).

\section{Prospects}

WINALPecobase is a crucial component for calibration and validation within the WINALP project. Thus, the database allows to compute average indicator values (Ellenberg et al. 2001) and queries concerning e.g. available water storage capacity, depth of decalcification, and hydromorphic mottling from soil profile data. By intersecting plot locations with GIS-layers of physiographic variables contained in the WINALP information system a wide array of additional ecological attributes can be generated. In the context of climate change research, the availability of a high resolution climate model (normal period 1971-2000, mean monthly temperature and precipitation, Hera et al. 2012) as well as climate change scenarios are of particular interest. The enlarged database will be suitable to verify GIS-mapping of potential forest types and to analyse and model direct ecological gradients like moisture, nutrient and thermal gradients across the Bavarian Alps. It also offers numerous opportunities for further investigations with respect to species-community-soil relationships. Thus, we invite collaborators to use WINALPecobase data for their own research and to design new studies jointly.

\section{Acknowledgements}

The research was generously funded under the project WINALP by the European Fund for Regional Development (EFRE), the Bavarian Ministry for Nutrition, Agriculture and Forestry (StMELF) and the Bavarian State Forest Enterprise (BaySF). We thank the inventory teams for mastering rough conditions, the Forest Administration for supporting the fieldwork and the Bavarian Enviroment
Agency (LfU) for providing its standards of soil survey.

\section{References}

Ad-hoc-Arbeitsgruppe Boden (2005): Bodenkundliche Kartieranleitung. 5th ed. - Hannover: Bundesanstalt für Geowissenschaften und Rohstoffe.

Braun-Blanquet, J. (1964): Pflanzensoziologie - Grundzüge der Vegetationskunde. 3rd ed. - Wien: Springer.

Ellenberg, H., Weber, H.E., Düll, R., Wirth, V., Werner, W. (2001). Zeigerwerte von Pflanzen in Mitteleuropa. 3rd ed. Scripta Geobotanica 18. Göttingen: Erich Goltze.

Ewald, J. (1995): Eine vegetationskundliche Datenbank bayerischer Bergwälder (A vegetation database of the Bavarian mountain forests). - Hoppea 56: 453465. 


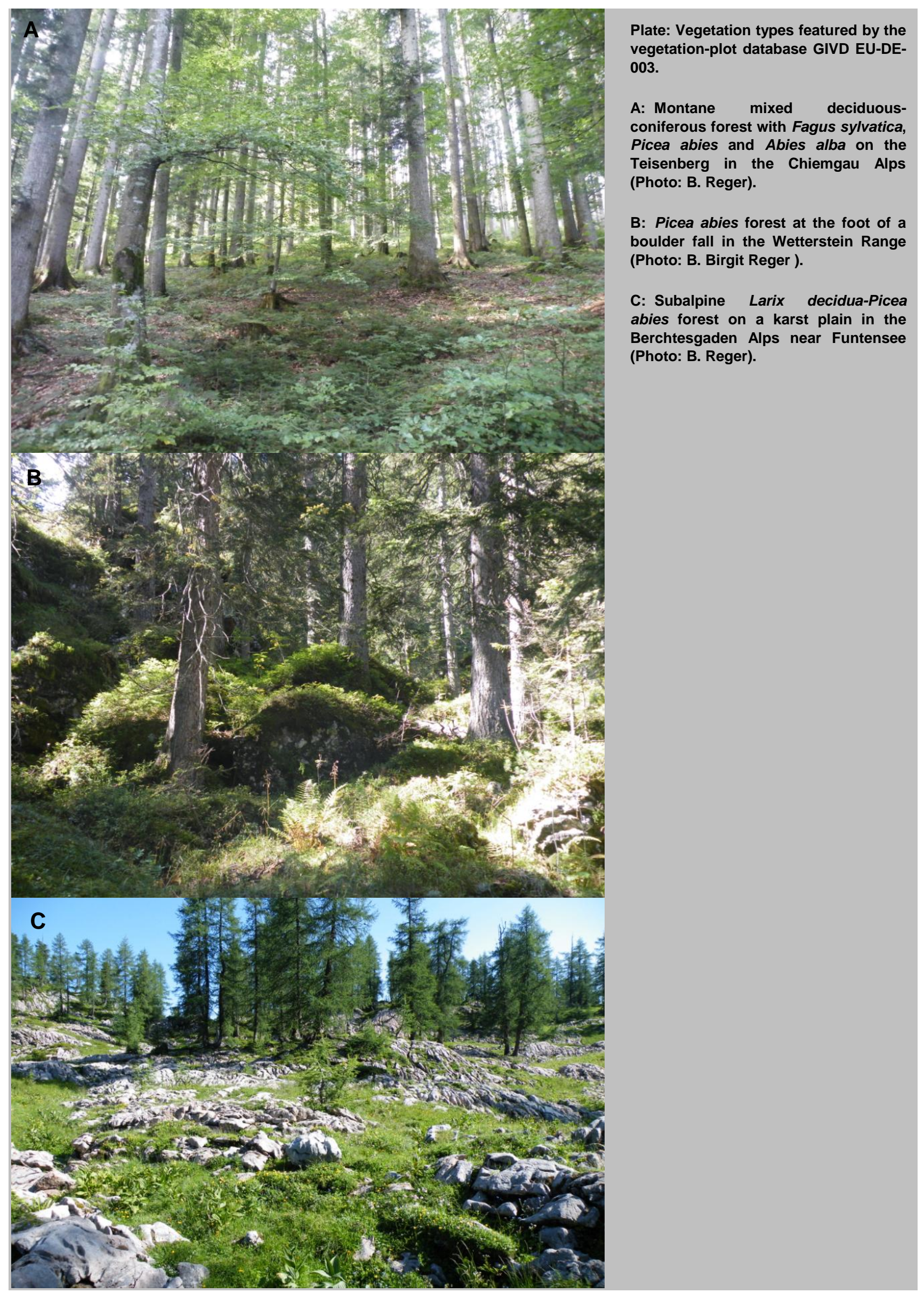




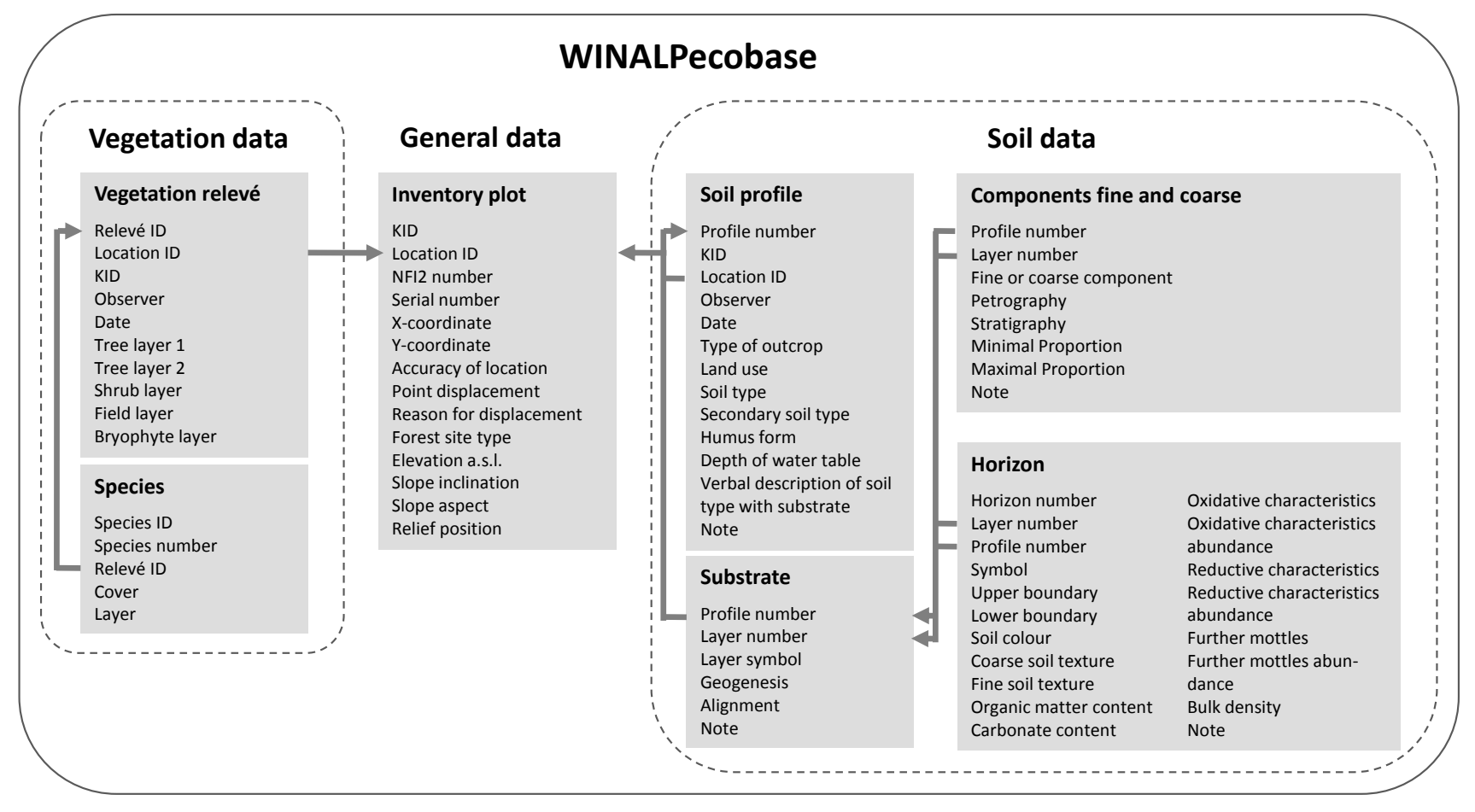

Fig. 2: Database structure of WINALPecobase.

Ewald, J., May, R., Kleikamp, M. (2006): VegetWeb - die pflanzensoziologische Online-Datenbank unter www.floraWeb. de. - In: Berg, C., Bergmeier, E., Hövelmann, T., Ristow, M. [Eds.]: Ein Netzwerk für den botanischen Artenschutz. - BfN-Skripten 178: 127-131.

Ewald, J., Binner, S. (2007): Werkzeuge zur Bestimmung der Waldtypen im bayerischen Hochgebirge [with English summary]. - Waldökologie Online 5: 2577. URL: http://www.afsv.de/download/ literatur/waldoekologie-online/wald oekologie-online heft-5-2.pdf.

Ewald, J. (2009): Waldinformationssystem Nordalpen - WINALP sammelt Wissen zum Schutz der Bergwälder (Forest information system for the Northern Alps WINALP collects knowledge for the protection of mountain forests). - Waldforschung aktuell 30: 45-46.

Ewald, J. (2012). BERGWALD - the vegetation database of mountain forests in the Bavarian Alps. - In: Dengler, J., Oldeland, J., Jansen, F., Chytrý, M., Ewald, J., Finckh, M., Glöckler, F., Lopez-Gonzalez, G., Peet, R.K., Schaminée, J.H.J. (2012) [Eds.]: Vegetation databases for the 21st century. - Biodiversity \& Ecology 4: 161-165. Hamburg:
Biocentre Klein Flottbek and Botanical Garden. CrossRef

Ewald, J., Reger, B. (2012). Bereitstellung von Standortsdaten im Waldinformationssystem Nordalpen (WINALP). - In: Clasen, M., Fröhlich, G., Bernhardt, H., Hildebrand, K., Theuvsen, B. [Eds.]: Informationstechnologie für eine nachhaltige Landbewirtschaftung - Fokus Forstwirtschaft: 79-82. Bonn: Gesellschaft für Informatik, Bonn. URL: http://www.hswt.

de/fileadmin/beuser/WF/Dokumente/

Ewald/Ewald Reger_2012 Abstract GIL.pdf.

Federal Ministry of Food, Agriculture and Consumer Protection (2005): National forest inventory. - Bonn: Bundesministerium für Ernährung, Landwirtschaft und Verbraucherschutz (BMELV). - URL: http://www.bundeswaldinventur.de/enid/ 3 e35fce339b0737fac9a0002bded40cc, 0 la9.html [accessed on 2010-07-30].

Jansen, F., Dengler, J. (2008): GermanSL - Eine universelle taxonomische Referenzliste für Vegetationsdatenbanken in Deutschland [with English summary]. Tuexenia 28: 239-253.

Hera, U., Rötzer, T., Zimmermann, L., Schulz, C., Maier, H., Weber, H., Kölling,
C. (2012): Klima en détail. - LWF aktuell 86: $34-37$

Birgit Reger*

(birgit.reger@lwf.bayern.de), Josefine Beck (josefine.beck@1wf.bayern.de), Elke Dietz (elke.dietz@1wf.bayern.de) Daniel Morovitz

(daniel.morovitz@lwf.bayern.de), Roman Schaller (roman.schaller@1wf.bayern.de)

\& Gerhard Wilhelm

(gerhard.wilhelm@1wf.bayern.de) Bavarian State Institute of Forestry

Hans-Carl-von-Carlowitz-Platz 1

85354 Freising, GERMANY

\section{Ralf Schüpferling}

(ralf.schuepferling@hswt.de) \&Jörg

Ewald (joerg.ewald@hswt.de)

University of Applied Sciences

Weihenstephan-Triesdorf

Hans-Carl-von-Carlowitz-Platz 3

85354 Freising, GERMANY

*Corresponding author 
